\title{
All Along the Watchtower
}

\section{Michael Hyde}

The following extract is a draft of a literary memoir, part of Michael's current PhD which examines the lived experience of the Sixties, the anti-Vietnam War Movement and the radical counter-culture in Australia.

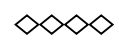

Bill and I boarded a Royal Air Cambodge plane for Phnom Penh. We wheeled into the blue sky and an uncertain adventure. I dreamily watched Hong Kong fall away as we turned in the direction of Southern Vietnam. An hour later we watched as a dark green canopy rolled away below us as we ate French cuisine, a by-product of that country's colonial empire. Occasionally I saw coils of smoke and glimpses of villages hidden in the forest and speculated that perhaps Brian Hamilton was slogging through the mud and heat down below as I flew above. At the same time I was happy that Sam 


\section{Michael Hyde}

was nowhere near the place they wanted him to be.

An hour into our journey and we began to notice something that looked like fires, or explosions of some kind. Smoke began to billow over the jungle rooftop, and flashes, like detonations, erupted over the landscape below. We asked the steward what it meant. He smiled comfortingly and assured us that it was cooking fires, or maybe a forest fire that had got out of control. I looked again but we entered a bank of cloud and whatever it was, was lost.

Cambodia was an ex-French colony with a royal leader, Prince Norodom Sihanouk, who was adamant that his country wouldn't be swallowed by America and who kept an eagle eye out for the machinations of the CIA. Meanwhile, he tried to steer a course between the Khmer Rouge and several other political groupings in his country.

Phnom Penh had a laid-back feel to it, old colonial architecture, patisseries, cyclos, rickshaws and the expat set around the classier hotel swimming pools. We found a room in a modest hotel in the centre of the tiny city and collapsed onto our beds. Hours later I woke to find Bill ferreting around in his pack.

'What's up mate?'I asked.

'Nothing to worry about. Thought I'd mislaid the five hundred dollars for a minute but it's still here.'

We'd converted the donation to the NLF into travellers cheques which Bill had kept in a pocket in his shoulder-bag. 'Listen mate', Bill said, 'I took the liberty of ringing the NLF Consulate. Told them we wanted to visit them. Didn't say why or any of that - I presumed the CIA would be tapping their phones.'

'So - when are we going?' I rolled off the bed and felt hungry. 
'Two days time. It's about half an hour out of town, so he told us to get a taxi. Wish it was sooner. I'll feel better when we get rid of the bloody dough.'

'Me too. Wanna get some food?'

I moved over to the window and peered down on the street. It was like a Graham Greene novel; expats strolled around in their creams and whites, a few travellers in shorts and t-shirts fossicked in dark shops, rickshaw men slept, sprawled on their seats and little kids ran around in the early evening. On one corner, a bulky gentleman lounged against a post, smoking one cigarette after another, every now and then he looked up at our window.

'Have a look at this, Bill,' I said. 'Don't want to get paranoid but by the pile of butts around him I'd say he's been there a while.' Bill stood to one side of the window and checked him out. Sure enough, he'd take a drag and then glance up to where we hid behind the curtains. 'Well ASIO would know for sure we're here and I guess they'd have good relations with all the spooks in Southeast Asia. Why don't we go and eat - see if he follows us.'

'Sure', smiled Bill. He was better in these situations than I was. He didn't appear fazed by the possibility of our movements being monitored.

The café next door sold a mixture of French pastries and original Cambodian dishes. At least our resident secret agent didn't join us but he moved and took up station directly opposite our café. It was so obvious that we figured that they'd been listening to FBI man, J. Edgar Hoover and wanted us to feel jumpy and watchful. I was famished and forgot the cardinal rule of not eating salad washed in water infested with bacteria and a few parasites. The next morning 
my folly came back to bite me. About six am my stomach rumbled ominously and a tidal wave of nausea swept everything before it. I staggered to the toilet in the nick of time, but as I sat there with sweat pouring from me and splashing onto the tiles, I was forced to leap from the seat and vomit into the bowl. For the next thirty minutes my orifices took it in turns - I found myself in a quandary about what end to point towards the toilet and felt some strange relief when I realised that nothing was coming from my ears.

Bill checked on me periodically but I could only manage a deathly moan. After half an hour there was nothing left, not even bile, and Bill, with a scarf covering his mouth and nose, entered the bathroom and hauled me back to my bed, with my jocks still around my ankles. He immediately gave me a double dose of Stemetil. I lay there and stared blankly at the walls. I felt like dying which I thought wasn't such a bad option, although meeting the end of my life on a lumpy bed in a cheap hotel miles from my home and loved ones wasn't the way I'd choose to go.

'How're you going?' asked my friend.

I replied with what I thought was a wan smile and gave a feeble thumbs-up. 'Fuckin' terrific', I whispered. 'Never better.'

'That's good, mate. 'Cause I thought we could head off to Angkor Wat. We got a couple of days up our sleeves.' But I didn't hear him; fortunately l'd lost consciousness.

Four hours later, I awoke. My sheets were soaked and I was several stone lighter but feeling marginally better. The door opened and Bill walked in with some medicine, a local remedy that would get my system back into harness.

'What is it?' I looked at the mixture of herbs. 
'Dunno', said Bill, 'but I was assured it would help. You're supposed to make it into a tea.'

Several pots later, I began to feel some strength returning and although I frequently went to the toilet, I was able to get up and slowly walk around.

'How's our spy going?'

Bill laughed. 'Followed me all the way to the local herbalist. Probably thought I was buying some pot. I saw him go into the shop after I left. So by now he's discovered that one of us has a bit of dysentery.'

'A bit of dysentery? That's like being a little bit pregnant. I tell you mate, it's like nothing I've ever had - and whatever it is, it's still there.'

Bill looked out the window. 'Hey Mike - D'you reckon you could cope with a bus ride? I'll carry your pack.'

I thought for a minute and although I felt like a ninety-year-old man, I didn't relish the idea of staying in a steaming hotel room for a couple of days with only the secret agent for company. I nodded my head and within the hour we were seated in a local bus en route to Siem Reap, the closest town to the jungle ruins of Angkor Wat. I'd never heard about Angkor Wat until one of the tour members in China mentioned it.

We were only there for a day, but I wondered why I'd never heard of it. Mile after mile of stone peaks, bas-reliefs, steep rocky steps, temples and wide stone causeways in the middle of a jungle that threatened to engulf it all. Perhaps I'd not learnt about it because the education wed received was so Euro-centric, so culturally cringing that anything that wasn't connected to British or US imperialism 
didn't get a look in. Black History virtually didn't exist in the schools and universities - the 1967 referendum to include Indigenous people in the census had just passed - and Australian History had only recently gained a toe-hold in the world of academia.

Luckily, my bilious condition slowly improved and after a night in another cheap little dive and managing to keep down a few meals of boiled rice, Bill and I found ourselves at the Angkor café hiring bikes to explore the ruins. A dirt road led into the darkness of the jungle, steaming in the midday sun. The humidity rose and we knew that we'd only have a couple of hours before the monsoon rains would begin to pour from the heavens. I pedalled slowly, trying to keep my mind off my bowels and my fear of being further away than a hundred yards from a toilet (I had amused Bill with my star ratings for them, most of them falling somewhere between quarter and half a star).

However, Angkor Wat overcame most of my worries - the five hundred dollars, the war, nightmares of jail, conscription, the whys and wherefores of the Cultural Revolution, Australia and family and mates - were lost in the stone carvings and mystery of Angkor Wat. Shadows fell across the dusty yellow road as we followed small tracks that ran off into thousand-year-old forests of banyan trees and vines. Stone archways and grey faces, blotched by white lichen, appeared out of nowhere. Bas reliefs depicting battles and telling stories of Ramayana hid in the undergrowth where the occasional small snake slithered. Steep flights of steps rose to nowhere and faces of the Buddha gazed into nothingness.

Back on the main road I signalled to Bill that I thought I could last about ten minutes before I'd embarrass myself. He was about to 
answer when a horde of monkeys suddenly went berserk and began to screech and yowl in the treetops all around us. They kept this up for some minutes before a couple of them climbed down the vines and began to scamper and wrestle in the dirt. Some males snarled in our direction and leapt in the air, as though egging each other on. One of them threw their own shit at us and some more of their tribe joined the leaders. 'Let's piss off, mate, Bill commanded and we made a run for it. A few of the bigger males chased after us but soon lost interest as we hurled ourselves back down the road.

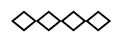

It took ten minutes of furious pedalling before we made it back to the safety of the little café. Once I'd purged myself, I asked Bill what he thought had spooked the monkeys. Bill shrugged his shoulders and jokingly suggested that it might have been the work of the spy, who we hadn't caught sight of since leaving Pnomh Penh. I asked the café owner about the reason for this hostile behaviour. 'Do not know', he answered. 'Maybe tiger. Maybe python. Bill and I looked at each other and forced a grin. And at that moment I completely forgot about my parasites and for the first time in two days began to feel better.

The afternoon rains fell like clockwork. They always started with a few fat drops, big as mangoes, that fell on hot tin rooves and thudded onto thick green leaves. Two minutes later the real event poured from the sky. It was like a waterfall that crashed to the earth and ran in rivulets and swamped everything before it, the road, the curtained roots of the banyan trees, the impassive stone Buddhas, 
and, we hoped, the belligerent army of monkeys. For the rest of the afternoon we sat mostly in silence, a silver screen of water blurring the landscape.

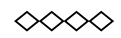

Back in Pnomh Penh we returned to our hotel and by twelve the next day we travelled by taxi to the 'Consulate Liberation Fronte de Sud Vietnam'. I would have the job of explaining why we had come so far just to donate what, when you thought about it, was less than a drop in the ocean. My failed schoolboy French was to do the honours.

Half an hour later we pulled up outside a two storey house with damp creeping up the walls. Dark green vines and cracks crawled around long shuttered windows.

We rang the bell and waited for a good five minutes before the door opened and were welcomed by a polite man in a suit, wearing a pair of rimless glasses. He took us into the sitting room where we sat around a dark polished coffee table, doilies arranged on the surface like rosettes. On the walls were the customary portrait of Ho Chi Minh, the NLF flag and photos of the NLF shooting down American planes and fighters gathered around wreckage, brandishing guns and smiles.

After the customary greetings I explained why we had come and what we wanted to give him. As the light dawned on the official via my pidgin French, he leapt to his feet and rushed for the cabinet, pulling out bottles and cigarettes. He turned and presented us with crystal glasses full to the brim with apricot liqueur.

'To the NLF. To the success of the Tet Offensive,' he laughed. 
We drank and smiled but Bill asked me what the Tet Offensive was all about. The official beamed and was clearly jumping out of his skin with excitement. Again I had to resort to my crap rendition of French: 'Excusez-moi, mais quest ce que c'est Tet Offensive?'

Inch by inch, bit by painfully translated bit, we understood the enormity of what had happened, what had taken place only the day before last. He kept filling our glasses, sitting down and then getting up and pacing around the room, sucking on a cigarette as he told us the story.

The NLF had simultaneously attacked numerous targets all over South Vietnam. The US Embassy in Saigon was under fire. The sister city of Saigon, Cholon, was taken over, American and Saigon Army installations were under siege, the radio station was captured - on and on until Bill asked whether I'd translated accurately.

Some of the detail escaped me but there was no doubt that it had happened. The Tet Offensive of 1968 was already being celebrated across the world, initiating demonstrations and editorials in the Western press which questioned the effectiveness of the American war machine and its apparent loss of control.

'When did this start?' asked Bill.

I didn't have to ask our jubilant Vietnamese friend. I knew the answer. Bill and I stared at each other and remembered the explosions, smoke and fire we'd seen from the plane a few days earlier - bright flashes in a dark green jungle - and knew that we had flown over South Vietnam on the first day of the offensive. Christ. It was enough to make me forget about my dysentery.

Later, when we returned to Australia, the movement against the war was still agog over what the Vietcong had achieved. The 


\section{Michael Hyde}

offensive had proved the NLF could attack anywhere, anytime something that could not be achieved without the tacit and active support of the majority of the South Vietnamese population. And although it widened cracks in the Establishment's fortress of deceit and righteousness and laid the groundwork for their eventual victory, it wasn't until many years later that I realised how much it had cost the NLF in lives, weaponry and organisational networks.

After our fourth drink, I found I was smiling foolishly and thinking that the official bore a striking resemblance to the young Ho Chi Minh. Thank god Bill could hold his liquor. He reached into his pocket and standing up, offered the cheques to the official with a slight bow of his head. The rains had already made their customary appearance, lashing against the windows and thunder made the building shudder and our glasses on the table tremble.

I stood up and said with as much reverence as my French allowed, 'This small donation is for the work of the National Liberation Front. It is from your supporters in Australia. We would like a receipt to take back home to help our fight against our government that is trying to stop us from supporting the NLF. Ten minutes later we drove away from our smiling friend, the receipt hidden in Bill's inside pocket. Sure enough, our other friend was back at the hotel. He sat at a café, smoking Gitanes and drinking coffee. We smiled and waved to him - he looked everywhere but in our direction. It was good to stick it up the spooks.

$\infty \infty$

While Bill tucked into a chicken dish surrounded by a suspicious looking red sauce, I slowly ate yet another bowl of rice. I looked like 
a shadow of my former self and commented to Bill that diarrhea was a great way of losing weight. Bill stopped eating and said, 'Thanks for sharing that with me, Mike. Now if you'll excuse me I'll just finish my meal.' I had a bad habit of making inappropriate remarks.

After dinner we mooched along the street, the city alive with cafés and food stalls and the ringing of bells as cyclos and rickshaws meandered through crowds of people. The roads were wet and steam rose from the pavements. Mosquitoes buzzed around our heads and legs and I hoped that our malaria tablets were doing their job.

While we examined cheap souvenirs of Buddhas with pointed hats and bamboo flutes and whistles, Bill asked me if I'd heard from my friend who'd gone to Vietnam. I hadn't but he was never far from my mind. I shook my head.

'What about Sam? He going OK?'

'Last I heard he was safe and sound but I suppose they'll move him on soon. Weird, isn't it Bill - here we are and there's Sam and there's Brian. Spread out all over the place, different sides of the fence, doing things we'd never imagined doing... strange eh?'

Bill finished his meal and licked his fingers. 'We've got a few days until we leave, how about visiting Wilfred Burchett. He's been living here for a few years. We could ask for an interview.

\section{$\infty \infty$}

Burchett was an iconic figure. An Australian journalist who had covered the Chinese fight against the Japanese and uncovered the American germ warfare program during the Korean War. In the mid-fifties his British passport had been stolen, most likely by the 
CIA and so far the Australian Government had refused not only to furnish Burchett with another passport but had also rejected his attempts to register his three children as Australian citizens. He had travelled the world for well over ten years with a 'laissez-passer' document provided by the French.

He was particularly interesting to us because of his coverage of the Vietnam War - he'd travelled with the Vietcong and North Vietnamese forces along jungle roads, and had interviewed such people as Cambodia's Prince Norodom Sihanouk, Vietnamese President Ho Chi Minh and General Giap who was famous for his victory over the French at Dien Bien Phu in 1954. He could have been granted a new passport by now but his problem was that he was a man of principle. If he'd shut his mouth and not been so insistent on giving accounts of the war from the 'other side', if he'd not been so determined to be a journalist with heart and resolve, we could have interviewed him in Lygon St or Balmain.

We rang Burchett's home that night, pessimistic about our chances. The next morning, to our surprise, we received a call from a Cambodian government official: 'Monsieur Burchett would be happy to meet you this afternoon.'

At two pm and our taxi drove down a dusty road that ended at the residence of Monsieur and Madame Burchett and their little daughter, Anna. It was a modest house with a thatched roof, surrounded by a rambling garden, pots of tropical plants and a profusion of fragrant flowers - a ladder rested against a mango tree and a small monkey chattered in the shadows of the foliage.

Wilfred Burchett emerged from the house, a broad smile on an even broader face. He wore black glasses and an open-necked shirt 
that hung over black pants. After introducing his wife and child, we sat around a garden table and were treated to two hours of information about the war, analysis of the American domestic situation, his time spent with the Vietcong, the possibility of Peace Talks in Paris, and a discussion on ethics and his well-known sympathy for the cause of socialism. After a while we forgot about our list of questions - he covered everything that we wanted to know and then some. Burchett was gentle, clear and erudite with a sense of humour you could only wonder at.

'I myself have certainly favoured the socialist system but that doesn't mean on every story I have to slant it in favour of that. I think firstly you have to have a sense of social responsibility. All I ask of my colleagues on all subjects is to consider themselves as social human beings. They have their livings to make; they have their wives and the rent to pay and one doesn't expect any miracles from them but I think people, whatever they are doing, wherever they are, they should behave as members of human society and not take this idea that they are some sort of dispassionate machine.'

Time moved lazily in the tropical afternoon as my tape recorder captured every minute of this remarkable moment in my life. For the first time since we arrived in Cambodia, there was no mid-afternoon downpour. I looked up through the trees and realised that the South Vietnam border lay only a short distance away to the east.

We headed there at seven am the next morning. At the end of our interview Burchett had invited us to accompany him and his son as part of an International Control Commission visit to Phnom Denh, an area close to the Cambodian/South Vietnamese border. The Cambodians claimed that it had been shelled by the US - South 


\section{Michael Hyde}

Vietnamese forces and by what we saw, the allegations were true. Huts and duck ponds and animals were blown apart. I watched as one farmer wept as he told the Commission how his life had been ruined, not just by death and misery but also by the slaughter of his two water buffalo. The death of water buffalo presented as a lifeshattering event was difficult for my western mind to comprehend, until Burchett explained that it would be like us losing family members, our house, our jobs and indeed our future in one fell swoop. Bill and I squatted in the heat of the mid-morning sun and fell into silence, as villagers walked in a daze around their splintered lives. 